\title{
Mammalian Chromosomes In Vitro. On the Marker Chromosomes and Chromosomal Polymorphism of Strain L-P59
}

\author{
G. K. Manna \\ Department of Zoology, University of Kalyani, \\ Kalyani, Nadia, West Bengal, India
}

Received August 9, 1961

The tissue culture strain L-P55 had a mysterious origin. It was reported by Hsu and Klatt (1958) that in the Laboratory of Dr. C. M. Pomerat at Galveston, Texas, on cultivation of a piece of cartilage from human fetal foot, a vigorously growing fibroblast cell line designated as strain FF was established. Hsu and Moorhead (1957) reported the chromosome number of strain FF but later on when its caryotype was compared with others, it was revealed that the cytological characteristics of strain FF were more like those of murine origin rather than those of human origin. The cytological findings were further supported by transplantation experimental proof as well as by the presence of similar kind of marker chromosomes between strain $\mathrm{L}_{2}$ of murine origin and the strain FF. Since clone 929 of L-cells was maintained at the time of setting up strain FF in Dr. Pomerat's Laboratory in 1955, it has been suspected by Dr. Hsu that during cultivation of FF cells, some L-cells mysteriously had contaminated the culture which in course of time completely wiped out the cells of FF ; and without critical caryotype analysis, the wrong would never have been revealed (Hsu and Klatt 1958). Hsu and Klatt (1958), therefore, redesignated the strain FF to L-P55; L represents L-cells of clone 929 of mouse, and P55-at Dr. Pomerat's Laboratory in 1955.

The strain L-P55 of mouse cell was maintained in the laboratory of Dr. T. C. Hsu and for safety's sake, he used to maintain them in two separate sets : a) one set for regular work, and b) the other set as reserve, in the care of two technicians (see Hsu and Kellogg 1960). Late in 1958 the first set of cultures being completely lost, the reserve set had to be employed. However on examination, the cells of the reserve stock were found to be changed both metabolically and cytologically from those of original L-P55 (Hsu and Kellogg 1959, 1960). This transformed strain from L-P55 has been designated as L-P59 by Hsu and Kellogg (1960).

\footnotetext{
\& The author is indebted to Dr. T. C. Hsu for providing excellent facilities to work in his Laboratory at M. D. Anderson Hospital, University of Texas, Houston, Texas. This work was supported in part by grant DRG-269D from Damon Runyon Memorial Fund for Cancer Research Inc., and by grant G.5645 from the National Science Foundation made available to the author by the courtesy of Dr. T. C. Hsu.
} 
The present author had the opportunity of studying cytologically a sample of the reserve stock of L-P55 in the month on January, 1959, (better be called as primary set of L-P59) still grown in Eagle's medium with $5 \%$ horse serum before they were changed on to grow in McCoy's 5 a medium (see Hsu and Kellogg 1960). The result obtained in the above study has been presented in the paper.

\section{Observation and discussion}

The sample of strain L-P59 studied in January 1959 shows a heterogeneous chromosome constitution. Practically no two cells are identical in this respect (Table 1). Figs. 1 and 2 show the presence of two dicentric chromosomes (D-chromosome of strain L-P55), one in each cell, while there is in addition a pseudo-D in the former and a conspicuously large submetacentric in the latter. Sometimes, when there is either the D-chromosome or the pseudo-D in a cell, their identification becomes a bit difficult because the position of the secondary constriction in pseudo-D corresponds to the position of the primary constriction of D-chromosome, and the two chromatids are very closely apposed at this point. The second constricted region of D-chromosome if not of primary nature, as this has not been verified from anaphase division, the two chromosomes will then be derived from a common one. Besides the D-chromosome, some conspicuously small chromosomes known as minute chromosomes may serve as the marker chromosomes. However, their extremely small appearance makes it difficult for detection. In good many cases, the D-chromosome or the pseudo-D is absent (Figs. 5, 6) while in others they are replaced by a polycentric chromosome (Figs. 3, 4). The polycentric chromosomes are seen to have three (Fig. 4) to as many as six centric constrictions assuming a centiped-like appearance very strikingly larger than any chromosome of the complement (see Plate I, Fig. 2 of Hsu and Kellogg 1960). The polycentric chromosomes are assumed to have been derived from the dicentric ones because in a cell where a polycentric one is present, the dicentric one is not seen. In some cells none of the large marker chromosome is present (Fig. 5) or in some other a conspicuously large $\mathrm{V}$-shaped chromosome appears as a marker instead of polycentric ones.

Some of the metacentric chromosomes sometimes show a minute deeply stained region in between two understained regions in the exaggerated area of the centromeric region (Fig. 4). Perhaps these chromosomes are in reality dicentric having the two centromeres very close to each other. It is likely that many of the dicentrics originate from the centric fusions of two acrocentric or telocentric chromosomes. In some cases one can not be sure if the dicentric chromosomes are real ones formed by structural changes or they are formed owing to heterochromatic associations between two different chromosome ends forming the faked ones. The other possibilities in the origin of dicentric and polycentric chromosomes are also not ruled out. 

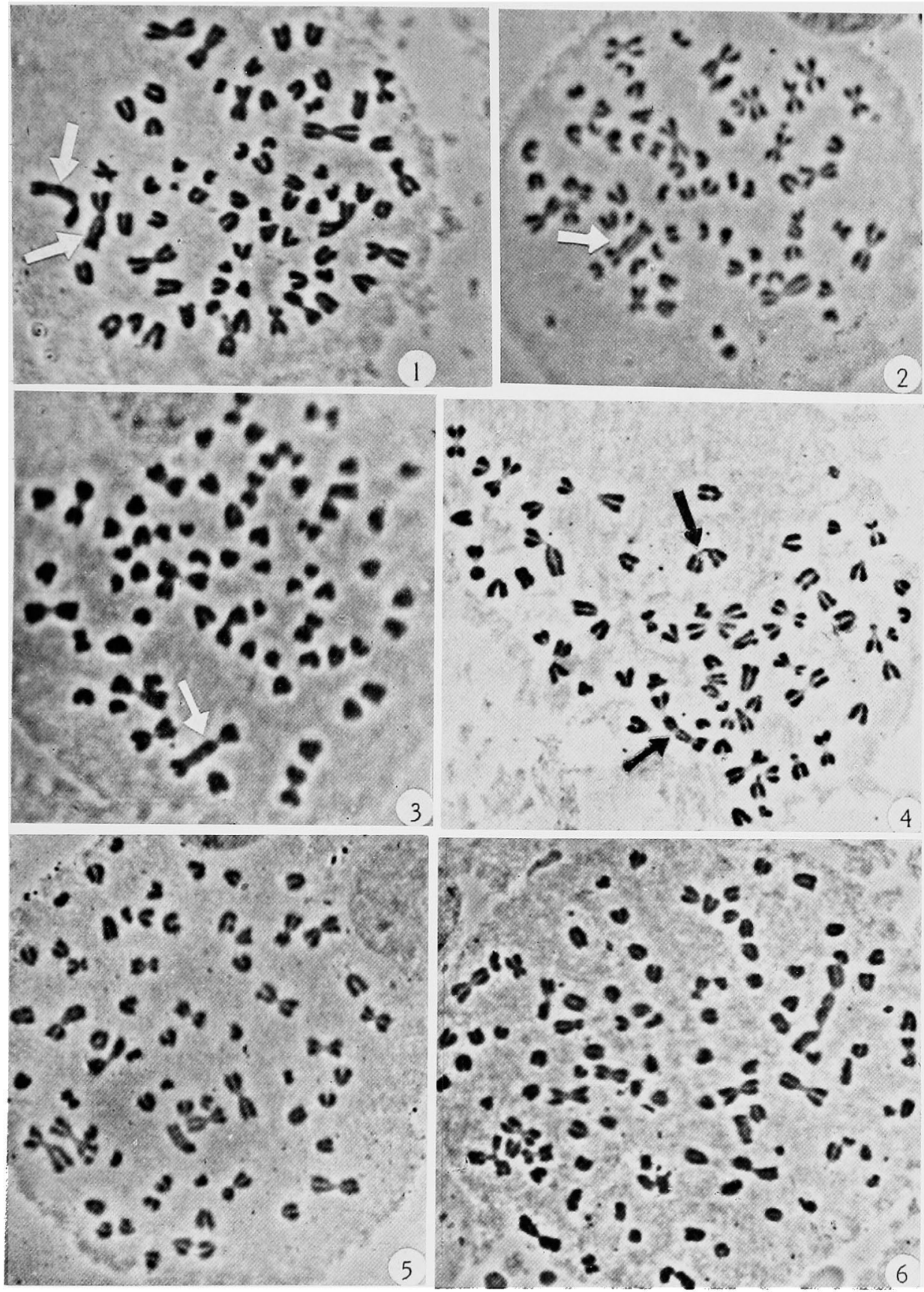

Figs. 1-6. 1, metaphase with 68 chromosomes including a D-, pseudo- D lying close to each other and a minute chromosome nearby. 2, metaphase with 66 chromosomes, presence of D-chromosome only. 3, metaphase with 66 chromosomes. Note the relatively large size of the D-chromosome. 4, metaphase with 66 chromosomes. Note the polycentric chromosome with 3 constrictions and other metacentric chromosomes with exaggerated centromeric region. 5 , metaphase with 63 chromosomes. Note the absence of the D-chromosome. Two metacentric chromosomes with chromatid breaks lying closeby. 6 , metaphase of a high polyploid cell showing the absence of D-chromosome. 
Table 1. Frequency distribution of chromosome numbers and their analyses in fifty nuclei of L-P 59

\begin{tabular}{|c|c|c|c|c|c|}
\hline $\begin{array}{l}\text { Chrom. } \\
\text { number }\end{array}$ & Types & $\stackrel{\text { of }}{\mathrm{M}}$ & $\begin{array}{l}\text { chromo } \\
\text { SM }\end{array}$ & A & Remarks on marker chromosomes \\
\hline 57 & 1 & 16 & 1 & 39 & Pseudo-D present \\
\hline $\begin{array}{l}59 \\
59\end{array}$ & 1 & $\begin{array}{l}13 \\
16\end{array}$ & $\begin{array}{l}3 \\
1\end{array}$ & $\begin{array}{l}42 \\
42\end{array}$ & $\begin{array}{l}\mathrm{D}+\text { one minute chromosome } \\
\text { One very long } \mathrm{V} \text { +one J-shaped }\end{array}$ \\
\hline $\begin{array}{l}60 \\
60 \\
60 \\
60 \\
60 \\
60\end{array}$ & $\begin{array}{c}2 \\
1 \\
2 \\
1 \\
1\end{array}$ & $\begin{array}{l}14 \\
15 \\
15 \\
14 \\
17 \\
13\end{array}$ & $\begin{array}{l}1 \\
4 \\
1 \\
2 \\
1 \\
1\end{array}$ & $\begin{array}{l}43 \\
40 \\
42 \\
43 \\
42 \\
45\end{array}$ & $\begin{array}{l}\mathrm{D}+\text { Pseudo-D } \\
\mathrm{D}+\text { long V } \\
\mathrm{D}+\text { Pseudo-D } \\
\text { Long V } \\
\text { Polycentric with } 6 \text { centromeres }\end{array}$ \\
\hline $\begin{array}{l}61 \\
61 \\
61\end{array}$ & $\overline{1}$ & $\begin{array}{r}9 \\
18 \\
15\end{array}$ & $\begin{array}{l}4 \\
1 \\
1\end{array}$ & $\begin{array}{l}48 \\
41 \\
44\end{array}$ & $\begin{array}{l}\text { Long } \mathrm{V} \text { tone minute } \\
\text { Polycentric with } 3 \text { centromeres } \\
\text { Pseudo-D } 1 \text { long metacentric }\end{array}$ \\
\hline $\begin{array}{l}62 \\
62 \\
62\end{array}$ & $\begin{array}{l}1 \\
1 \\
1\end{array}$ & $\begin{array}{l}14 \\
14 \\
17\end{array}$ & $\begin{array}{l}2 \\
2 \\
1\end{array}$ & $\begin{array}{l}45 \\
45 \\
43\end{array}$ & $\begin{array}{l}\text { Pseudo-D+one minute } \\
\text { D+one long submetacentric } \\
\text { Polycentric with } 3 \text { constrictions }\end{array}$ \\
\hline $\begin{array}{l}63 \\
63 \\
63 \\
63 \\
63 \\
63 \\
63 \\
63\end{array}$ & $\begin{array}{r}2 \\
1 \\
1 \\
1 \\
1 \\
1 \\
1 \\
1\end{array}$ & $\begin{array}{l}15 \\
13 \\
11 \\
13 \\
15 \\
12 \\
16 \\
13\end{array}$ & $\begin{array}{l}1 \\
3 \\
3 \\
3 \\
1 \\
1 \\
3\end{array}$ & $\begin{array}{l}45 \\
46 \\
49 \\
46 \\
46 \\
49 \\
45 \\
46\end{array}$ & $\begin{array}{l}\text { Pseudo-D+polycent. with } 4 \text { constr. } \\
\text { Pseudo-D+long V } \\
\text { Very long V } \\
\text { Polycentric with } 3 \text { constrictions } \\
\text { Polycentric with } 3 \text { constrictions } \\
\text { D+one ring chromosome } \\
\text { Pseudo-D }+1 \text { long submetacentric } \\
\text { Pseudo-D }+1 \text { long submet. }+1 \text { minute }\end{array}$ \\
\hline $\begin{array}{l}64 \\
64 \\
64\end{array}$ & $\begin{array}{l}1 \\
1 \\
2\end{array}$ & $\begin{array}{l}15 \\
12 \\
15\end{array}$ & $\begin{array}{l}4 \\
2 \\
3\end{array}$ & $\begin{array}{l}44 \\
49 \\
44\end{array}$ & $\begin{array}{l}\mathrm{D}+1 \text { long } \mathrm{V}+2 \text { minutes } \\
\mathrm{D}+1 \text { long } \mathrm{V} \\
\text { Pseudo-D }+ \text { Polycen. with } 3 \text { constric. }\end{array}$ \\
\hline 65 & 1 & 14 & 1 & 49 & $\mathrm{D}+$ one minute \\
\hline $\begin{array}{l}66 \\
66 \\
66 \\
66 \\
66 \\
66 \\
66 \\
66 \\
66 \\
66\end{array}$ & $\begin{array}{l}\frac{-}{1} \\
\frac{1}{1} \\
\frac{1}{1} \\
1\end{array}$ & $\begin{array}{l}11 \\
12 \\
15 \\
13 \\
13 \\
12 \\
15 \\
12 \\
13 \\
17\end{array}$ & $\begin{array}{l}4 \\
4 \\
3 \\
3 \\
2 \\
3 \\
3 \\
4 \\
2 \\
-\end{array}$ & $\begin{array}{l}51 \\
50 \\
47 \\
50 \\
50 \\
51 \\
47 \\
50 \\
50 \\
48\end{array}$ & $\begin{array}{l}\text { Long V } \\
\text { Long V } \\
\text { D+one long V } \\
\text { Long V+tone minute } \\
\text { Long V+two minutes } \\
\text { D+one long submetacentric } \\
\text { Long submetacentric } \\
\text { Pseudo-D+one long V } \\
\text { Pseudo-D+one minute }\end{array}$ \\
\hline $\begin{array}{l}67 \\
67 \\
67 \\
67 \\
67 \\
67 \\
67\end{array}$ & $\begin{array}{l}1 \\
- \\
- \\
- \\
- \\
1\end{array}$ & $\begin{array}{l}15 \\
15 \\
12 \\
14 \\
11 \\
11 \\
15\end{array}$ & $\begin{array}{l}1 \\
2 \\
2 \\
2 \\
2 \\
2 \\
1\end{array}$ & $\begin{array}{l}50 \\
50 \\
53 \\
51 \\
54 \\
54 \\
50\end{array}$ & $\begin{array}{l}\text { D+one minute } \\
\text { Very long } V \\
\text { Long } V \\
\text { Long } V+\text { two minutes } \\
\text { Long } V \\
\text { Long } V+\text { one minute } \\
D+\text { tone long submet. +one minute }\end{array}$ \\
\hline $\begin{array}{l}68 \\
68 \\
68 \\
68\end{array}$ & $\begin{array}{c}- \\
1 \\
1\end{array}$ & $\begin{array}{r}16 \\
9 \\
17 \\
13 \\
\end{array}$ & $\begin{array}{l}1 \\
2 \\
1 \\
1\end{array}$ & $\begin{array}{l}51 \\
57 \\
49 \\
53\end{array}$ & $\begin{array}{l}\text { Long } \mathrm{V} \text { tone minute } \\
\text { Long } \mathrm{V} \\
\text { Pseudo-D+one long submetacentric }\end{array}$ \\
\hline $\begin{array}{l}71 \\
71\end{array}$ & - & $\begin{array}{l}14 \\
13\end{array}$ & $\begin{array}{l}4 \\
4\end{array}$ & $\begin{array}{l}53 \\
54\end{array}$ & $\begin{array}{l}\text { Long } \mathrm{V} \\
\text { Long } \mathrm{V}+2 \text { minutes }\end{array}$ \\
\hline 64.16 & .72 & 13.84 & $4 \quad 2.08$ & 47.50 & Average \\
\hline
\end{tabular}

Abbreviations used: $\mathrm{D}=$ dicentric and polycentric; $\mathrm{M}=$ metacentric to submetacentric; $\mathrm{SM}$ =submetacentric to acrocentric; $A=$ acrocentric and telocentric chromosomes. 
An analysis of the data (Table 1) indicates a general trend that cells with higher chromosome number more often are without the D-chromosome and there is generally a large metacentric which stands out distinct from other chromosomes. The D-chromosomes show a variety of changes with regard to the number of constricted regions (Table 1). The number of metacentric, submetacentric and acrocentric chromosomes varies between 9 and 18 , none to 4 , and 40 to 57 respectively in different cells. The teiminologies - submetacentric and acrocentric chromosomes of this paper correspond to the subtelocentric and telocentric chromosomes respectively used by Dr. Hsu. The acrocentric chromosomes rather than metacentric and submetacentric ones appear to be responsible for the increase of the chromosome number as they are on an average more in the cells with higher chromosome numbers. The mean values of the chromosome numbers along with their different categorical divisions of the different samples of L-P59 taken in January and studied by Hsu and Kellogg (1960) agree considerably with those of the present paper (Table 1).

The chromosome constitution of the present sample of L-P59 forms the basis of a number of cell strain derivatives under the experimental condition as shown by Hsu and Kellogg (1960). The chromosomal polymorphism thus plays a vital role in the evolution of different caryotypes. The selection pressure operates more readily on cells in vitro rather than on cells in vivo (Manna 1961), since the cell environments in tissue culture are more variable and direct. The different chromosomal anomalies are thus not disadvantageous for the survivality of the cell strains. The heteroploid transformations of most of the cell strains are, therefore, a safeguard in the problem of survivality and propagation. In the present light, the 'stem line' hypothesis of Makino (1957) should be a flexible one and in a cell population there may be several potential genomes which act upon in different environments giving rise to the origin of new stem cells (Hsu and Kellogg 1960, Hsu 1960). The parental strain L-P55 from which L-P59 is derived had an average of 67.9 chromosomes per cell while the metacentrics 12.9, submetacentric (=subtelocentrics) 3.8, and acrocentrics (=telocentrics) 49.9, and dicentrics (D-chromosomes) 1.2 (Hsu and Klatt 1958). In L-P59 there are changes not only in the mean values of chromosome number but also in the marker chromosomes.

\section{Literature cited}

Hsu, T. C. 1960. Mammalian chromosomes in vitro. XIII. Cyclic and directional changes of population structure. J. Nat. Cancer Inst. 25: 1339-1353.

- and Kellogg, D. S. 1960. Mammalian chromosomes in vitro. XII. Experimental evolution of cell populations. J. Nat. Cancer Inst. 24: 1067-1093.

- and - 1959. Genetics of in vitro cells. Monograph Genetics and Cancer, Austin, Texas, Univ. Texas Press, 183-204.

- and Klatt, O. 1958. Mammalian chromosomes in vitro. On genetic polymorphism in 
cell populations. J. Nat. Cancer Inst. 21: 437-473.

- and Moorhead, P. S. 1957. Mammalian chromosomes in vitro. VII. Heteroploidy in human cell strains. J. Nat. Cancer Inst. 18: 463-471.

Makino, S. 1957. The chromosome cytology of the ascites tumours of rats, with special reference to the concept of stem line cell. Intern. Rev. Cytol. 6: 25-84.

Manna, G. K. 1961. Mammalian chromosomes in vitro. The chromosomes of Jensen sarcoma and its in vitro derivatives. Nucleus 4: 109-124. 